\title{
Epizootic haemorrhagic disease
}

\author{
N.J. Maclachlan ${ }^{(1,2)^{*}}$, S. Zientara ${ }^{(3)}$, G. Savini ${ }^{(4)} \&$ P.W. Daniels ${ }^{(5)}$ \\ (1) Department of Pathology, Microbiology and Immunology, School of Veterinary Medicine, University \\ of California, Davis, CA 95616, United States of America \\ (2) Department of Veterinary Tropical Diseases, Faculty of Veterinary Science, University of Pretoria, \\ Onderstepoort 0110, Republic of South Africa \\ (3) Université Paris Est, Unité mixte de recherche 1161, Agence nationale de sécurité sanitaire \\ de l'alimentation, de l'environnement et du travail, Institut national de la recherche agronomique, \\ École nationale vétérinaire d'Alfort, 23 Av. du Général de Gaulle, BP 63, 94703 Maisons-Alfort Cédex, France \\ (4) Istituto Zooprofilattico Sperimentale dell'Abruzzo e Molise 'G. Caporale', Teramo, Italy \\ (5) Commonwealth Scientific and Industrial Research Organisation, Australian Animal Health Laboratory, \\ PO Bag 24, Geelong, VIC 3220, Australia \\ *Corresponding author: njmaclachlan@ucdavis.edu
}

\begin{abstract}
Summary
Epizootic haemorrhagic disease (EHD) is an arthropod-transmitted viral disease of certain wild ungulates, notably North American white-tailed deer and, more rarely, cattle. The disease in white-tailed deer results from vascular injury analogous to that caused by bluetongue virus (BTV), to which EHD virus (EHDV) is closely related. There are seven serotypes of EHDV recognised, and Ibaraki virus, which is the cause of sporadic disease outbreaks in cattle in Asia, is included in EHDV serotype 2. The global distribution and epidemiology of BTV and EHDV infections are also similar, as both viruses occur throughout temperate and tropical regions of the world where they are transmitted by biting Culicoides midges and infect a wide variety of domestic and wild ungulates. However, the global distribution and epidemiology of EHDV infection are less well characterised than they are for BTV. Whereas most natural and experimental EHDV infections (other than Ibaraki virus infection) of livestock are subclinical or asymptomatic, outbreaks of EHD have recently been reported among cattle in the Mediterranean Basin, Reunion Island, South Africa, and the United States. Accurate and convenient laboratory tests are increasingly available for the sensitive and specific serological and virological diagnosis of EHDV infection and confirmation of EHD in animals, but commercial vaccines are available only for prevention of lbaraki disease and not for protection against other strains and serotypes of EHDV.
\end{abstract}

\section{Keywords}

Arbovirus - Culicoides midge - Epizootic haemorrhagic disease virus - Ibaraki virus Vaccination.

\section{Introduction}

Epizootic haemorrhagic disease (EHD) is an arboviral disease of certain wild ungulates, notably white-tailed deer (Odocoileus virginianus) and, rarely, cattle (1, 2, 3, 4). Although recognised earlier in the south-eastern United States, EHD was first described after a severe outbreak of the disease in white-tailed deer in New Jersey in 1955 (5). Epidemics of EHD continue to occur regularly in this species throughout much of North America east of the Rocky Mountains (1, 2, 6, 7, 8, 9, 10, 11, 12, 13). The disease also occurs sporadically in American pronghorn antelope and bighorn sheep, and was documented recently in brocket deer in Brazil and captive yaks in Colorado
(1, 2, 13, 14). Whereas EHD virus (EHDV) can cause a fulminant haemorrhagic disease syndrome in both experimentally and naturally infected white-tailed deer, similar infections of ruminant livestock and other wildlife species are generally subclinical or clinically inapparent (1, 2, 4, 15-35). For instance, although serological surveys indicate that EHDV infection of wild and domestic ruminants is prevalent throughout western North America, such infections are invariably subclinical or asymptomatic, and it is an adenovirus, and not EHDV or bluetongue virus (BTV), that is the cause of the haemorrhagic disease syndrome that occurs commonly among black-tailed and mule deer (Odocoileus hemionus) in the region (L.W. Woods, personal communication; 18, 28, 36). 
Since the initial description of EHD in the eastern United States, EHDV infection of wild and domestic ungulates has been identified elsewhere in the Americas (including the Caribbean islands and both Central and South America), Africa, Asia (including Eastern, Central and Southeast Asia), Australia, Indian Ocean islands such as Mauritius and Reunion, and the Middle East (4, 14, 16, 25, 30, 37-55). Although infection of domestic livestock is prevalent in many endemic areas, EHDV only rarely causes overt disease in livestock species and apparently only in cattle and not small ruminants $(4,23)$. A notable exception to the usually asymptomatic EHDV infection in cattle has been Ibaraki virus (EHDV serotype 2 [EHDV-2]), which caused an extensive outbreak of disease in Japanese cattle in 1959 and continues to sporadically cause disease outbreaks among cattle in the Far East (56, 57, 58, 59, 60). More recently, strains of EHDV-2, 6 and 7 have been the apparent cause of a bluetongue-like disease syndrome of cattle in northern and southern Africa, North America, Reunion Island, and the Mediterranean Basin, including Algeria, Israel, Jordan, Morocco, Tunisia and western Turkey (4, 6, 8, 39, 40, 49, $55,61,62,63,64)$.

Savini et al. (4) recently published a comprehensive review of EHD, so the goal of this paper is to summarise findings since that review and to provide a global perspective on the biology of EHDV infection.

\section{Aetiological agent}

Epizootic haemorrhagic disease virus is a member of the genus Orbivirus in the family Reoviridae. It is closely related to $\mathrm{BTV}$, which is the prototype member of the genus (65). All EHDVs share common group antigens that distinguish them from BTV, African horse sickness virus, and other orbiviruses. There is confusion in the historical literature regarding the number of serotypes of EHDV, but the International Committee for Taxonomy of Viruses now designates just seven serotypes of the virus based on recent serological and molecular analyses $(65,66,67,68,69)$. Ibaraki virus was initially classified as EHDV-7, but is now classified as EHDV-2, as it is genetically and serologically most similar to the prototype strain of EHDV-2 that was isolated in Alberta, Canada, in 1964. However, the serotype-specific L2 gene of Ibaraki virus shares only partial homology with isolates of EHDV-2 from North America, which are all more closely related to one another than they are to Ibaraki virus, whereas the genes encoding the VP3 and VP7 core proteins of Ibaraki virus are more conserved and are similar to those of Australian strains of EHDV-2 $(57,60,70,71,72,73,74)$. The similarity of the core protein genes of Australian strains of EHDV to those of Ibaraki virus indicates that they are all included in an Asian 'topotype' of EHDV that was recently designated as the 'eastern topotype', based on comparative phylogenetic analysis of the gene (segment 9) encoding core protein VP6 $(66,69)$.

Like other orbiviruses, the EHDV genome consists of ten distinct linear segments of double-stranded RNA. Each gene segment encodes at least one protein and the coding assignments and functions of each protein are assumed to be identical to those of BTV. The icosahedral EHDV virion includes seven structural proteins (VP1-7) and at least four non-structural viral proteins (NS1, NS2, NS3, NS3A) are produced in EHDV-infected cells (4, 65, 66, 67, 68). VP2 and VP5 form the outer capsid of the EHDV virion, and VP2 is responsible for serotype determination. The core protein VP7 expresses antigenic determinants that are common to all viruses in the EHDV serogroup (75).

There is considerable genetic variation among the strains of EHDV that circulate within endemic regions, including among virus strains of the same serotype $(6,11,73,76$, $77,78,79,80)$. For example, six serotypes of EHDV have been detected in the historically endemic area in northern Australia $(26,34,44,54)$, and at least three different serotypes currently circulate in North America $(76,77,81)$. Phylogenetic analyses of certain gene segments, notably segments 3 and 9, indicate that global strains of EHDV segregate into distinct 'eastern' (Asia and Australia) and 'western' (Americas, Africa, Mediterranean Basin) topotype lineages $(66,70,76)$. Although certain strains of EHDV are clearly more virulent for cattle than others, notably Ibaraki virus (EHDV-2) and the recently described strains of EHDV-2, 6 and 7 that caused disease among cattle in the Mediterranean Basin and on Reunion Island, the molecular basis of EHDV virulence is uncharacterised and other strains of these same EHDV serotypes (EHDV-2, 6 and 7) typically do not cause significant disease among cattle in other endemic regions of the world (4).

\section{Epidemiology and modes of transmission}

Both BTV and EHDV are arboviruses transmitted principally by haematophagous insects (Culicoides midges) that serve as true biological hosts of the virus $(3,4)$. It is assumed, therefore, that the epidemiological features of EHDV infection mirror those of BTV. Thus, although less well documented on a global basis, the distribution of EHDV infection likely is similar to that of BTV and includes tropical and temperate regions throughout the world between latitudes of approximately $40-50^{\circ} \mathrm{N}$ and $35^{\circ} \mathrm{S}$ $(4,25,31,37,38,44,45,46,47,48,49,50,51,52)$. It is assumed, but not well proven, that the specific vector species differ throughout the world. In North America, C. 
sonorensis is considered to be the predominant vector for both viruses, although it is recognised that other vectors, for example C. mohave, might be regionally important $(82,83$, 84). Interestingly, however, EHDV infection extends into the Canadian states of Saskatchewan and Alberta, whereas BTV does not $(12,82,85,86)$. In contrast, whereas BTV has recently invaded extensive portions of Europe, EHDV has not and Europe is currently free of EHDV infection despite the presence of the virus on the southern and eastern rims of the Mediterranean Basin (4).

Serological evidence of EHDV infection has been reported in many ruminant species, both wild and domestic, including sheep, cattle, various species of deer, elk, bison, mountain goats and ibex, as well as camels, llamas, rhinoceros, bears, yaks and marsupials $(1,2,13,37,50,87)$.

Female Culicoides insects become persistently infected with EHDV and can transmit the virus to susceptible ruminants after an external extrinsic period of approximately 10 to 14 days. Like BTV infection, viraemia can be prolonged in EHDV-infected ruminants because of a novel association of the virus with ruminant erythrocytes $(88,89)$. Truly persistent infection of ruminants has not been described with EHDV, although cattle likely serve as temporary reservoir hosts of both viruses $(15,19,20,21,22,23,26,44)$. The cycle of infection is completed when uninfected female Culicoides insects feed on viraemic ruminants. In temperate regions, infection is most common in the late summer and autumn when vector populations peak, whereas infection occurs year-round in tropical regions of the world. With global climate change, there appears to be a correlation between increasing ambient temperature and risk of EHDV infection (13). For example, the effects of subtle differences of ambient temperature on vector midges likely explain differences in the global distribution of BTV and EHDV in Europe and North America (4).

\section{Clinical signs}

Epizootic haemorrhagic disease manifests as a haemorrhagic disease in susceptible white-tailed deer, whereas EHDV infection is typically asymptomatic in domestic ruminants. In white-tailed deer, the disease is characterised by fever, weakness, inappetance, excessive salivation, facial oedema, hyperaemia of the conjunctiva and the mucous membranes of the oral cavity, coronitis, and stomatitis $(1,5,7,9,12)$. Fulminant EHD is characterised by excessive bleeding (haemorrhagic diathesis), dehydration, diarrhoea, and death. Affected animals exhibit increasing perturbations in blood coagulation, with progressive thrombocytopenia and prolongation of clotting assays such as the activated partial thromboplastin time and prothrombin time. The pathogenesis of EHDV infection of white-tailed deer appears to be similar, or in some cases identical, to that caused by BTV $(2,27,32,89,90,91)$. After the deer are infected, by the feeding of infected Culicoides insects, the virus first replicates in lymph nodes draining the site of virus inoculation. Virus is then disseminated to secondary sites of replication such as the lungs and spleen. Clinical manifestations reflect widespread vascular injury and subsequent disseminated intravascular coagulation, which leads to haemorrhage, oedema, and tissue necrosis (infarction). Microvascular endothelial injury is characteristic of fulminant EHD of white-tailed deer, and both BTV and EHDV clearly replicate in the endothelium of infected ruminants. Prolonged cell-associated viraemia occurs in both BTV- and EHDV-infected ruminants that survive acute infection, and viraemia persists despite the presence of neutralising antibody. Intimate association of virus particles with erythrocytes is likely responsible for prolonged viraemia, and provides a ready source of virus for the haematophagous Culicoides insect vector $(88,89)$.

The lesions of EHD in white-tailed deer are characterised by extensive oral ulceration and widespread haemorrhage and oedema $(1,2)$. Haemorrhage and oedema can vary considerably in extent and distribution, but often are present in the skin and subcutis, oral cavity, salivary glands, abomasum and forestomachs, lymph nodes, urinary bladder, serosal surfaces of the pleural and peritoneal cavities, endocardium, myocardium, pulmonary artery and aorta. Pericardial effusion and pulmonary oedema can be severe in acutely affected animals. Histologically, the lesions of EHD are characterised by haemorrhage and necrosis, with accompanying thrombosis of capillaries and small vessels in affected tissues. The tongue, salivary glands, forestomach, aorta, and myocardium, especially that of the papillary muscle of the left ventricle, are commonly affected. Similar lesions have recently been described in EHDV-infected yaks and brocket deer $(13,14)$.

Although outbreaks of Ibaraki disease with high mortality in cattle are well documented in Japan and Korea, serological surveys confirm that the majority of Ibaraki virus infections are subclinical $(56,57,58,59,60)$. The disease is characterised by stomatitis, and severely affected cattle exhibit difficulty in swallowing as a consequence of virus-induced myonecrosis of the tongue and oesophagus. Stillbirths and abortions also occur after infection of pregnant animals, and virus can be isolated from affected fetuses. Experimental Ibaraki virus infection of cattle typically causes mild signs, but severe disease with oral and interdigital ulcers can occur in some inoculated cattle. Ibaraki virus is not pathogenic for sheep.

The high seroprevalence of EHDV infection among ruminants in endemic areas indicates that most ungulates survive infection with the virus and experience only subclinical infections $(2,18,28,30,37,45,46,47,48$, 
49, 50, 51). In Australia, for example, where six serotypes of EHDV have been recognised, and five of these for more than 30 years (54), clinical disease attributable to EHDV infection has not been recognised. This, despite the comprehensive surveillance of the National Arbovirus Monitoring Program (92), which spans the boundaries of Culicoides vector distribution and includes observational surveillance across areas in which there would be seasonal variability in exposure of naive cattle populations to the virus. Furthermore, experimental infection of cattle with strains of EHDV isolated in the United States, the Middle East and Australia has consistently failed to induce clinical disease $(15,19,20,21,22,23,24,33)$.

Although most natural and experimental EHDV infections in cattle are subclinical or asymptomatic, the virus has recently been incriminated as a cause of outbreaks of stomatitis and systemic disease in cattle infected with EHDV-2 and 6 on Reunion Island and in western Turkey and North Africa, and in cattle infected with EHDV-7 in Israel and Jordan $(40,49,55,63,64)$. Similar syndromes have also been described among EHDV-infected cattle in both North America and South Africa (8, 39, 61, 62). Clinical signs described among cattle affected during these outbreaks include loss of appetite, fever and depression, nasal discharge, oral ulcers and excessive salivation, coronitis and lameness, and increasing dyspnoea and respiratory distress. Milk production was significantly reduced among affected dairy cattle during a recent epidemic of EHDV-7 in Israel (63). However, with the notable exception of Ibaraki disease, EHD typically results in negligible or very low mortality among cattle. Furthermore, although disease attributable to EHDV infections has been reported in cattle in North America it has been markedly less severe than the disease routinely seen in white-tailed deer, which are a particularly susceptible species. As with the related BTV, the basis of variability in virulence among viral strains and the basis of susceptibility to disease of some infected ruminant host species are as yet undetermined.

\section{Diagnosis}

Infection with EHDV is diagnosed by either virus detection or serology, or both. Virus detection is done either by virus isolation, which is inherently slow and requires specialised laboratory facilities, or viral RNA detection via polymerase chain reaction (PCR). The optimal tissues for virus isolation include anticoagulated blood, spleen, lung, and lymph nodes. The virus can be isolated by inoculation of either embryonated chicken eggs (ECE) or cell cultures $(2,3,4)$. Embryonated chicken eggs are generally considered more sensitive, although Australian strains of EHDV are isolated in ECE and Aedes albopictus cell cultures with equal sensitivity, suggesting that individual virus strains may differ in this regard $(26,44)$. There are as yet no comprehensive data available regarding successful isolation of EHDV after primary passage in cell cultures that have successfully been used for isolation of BTV, such as those derived from bovine endothelial cells or from Culicoides midges (KC cells).

Methods based on polymerase chain reaction (PCR) are now available for detection of EHDV nucleic acid, but diagnosis may be complicated by the fact that EHDV nucleic acid may persist in the blood of infected ruminants far longer than infectious virus. Quantitative PCR assays are the preferred strategy, as they are for BTV (93), since the amount of virus in an individual sample can be estimated, and the risks of laboratory contamination are reduced. Both serogroup-specific and serotype-specific real-time PCR assays are now available to quickly identify and serotype any EHDV contained within a biological sample (4, 69, 74, 94).

Serological methods for detecting EHDV group-specific antibodies in the serum of ruminants include the agar gel immunodiffusion test and a competitive enzymelinked immunosorbent assay (ELISA) that incorporates a monoclonal antibody to the EHDV group-specific antigen $(95,96)$, as reviewed by Savini et al. (4). Serotype-specific antibodies are detected by serum neutralisation assay, although such assays are laborious and require specialised laboratory facilities.

Differential diagnosis of EHD can be difficult, because the lesions in cattle can resemble some of those that occur in mucosal disease/bovine viral diarrhoea, malignant catarrhal fever, bovine ephemeral fever, bluetongue (BTV-8 in particular), and other diseases. Confirmation of the diagnosis of EHD in cattle is further complicated by the fact that EHDV infections can be very common among livestock in endemic areas, thus animals in these areas are often seropositive or subclinically infected with the virus; therefore, the mere presence of either antibody or EHDV in the blood of a livestock ruminant is not proof of disease causality. Serological cross-reactions with BTV may further complicate serological diagnosis of EHDV infection as animals infected with more than one serotype of EHDV can produce antibodies that cross-react with BTV in some serological assays, and the reverse also is true $(21,97)$. Thus, the presence of group-specific antibodies should always be confirmed with virus-specific serum neutralisation assays.

\section{Control measures}

Control of EHD might hypothetically be attempted via exclusion of the infection from a region or country (by preventing the introduction of infected animal hosts or vectors), or by using either preventive (prophylactic) 
or therapeutic strategies in endemic or incursive areas (reviewed, 4). Treatment of EHD-affected wildlife is generally impractical, and infections of livestock are rarely fatal. The exception is Ibaraki disease of cattle, in which dysphagia and aspiration pneumonia are important causes of mortality, so prevention and/or treatment of these abnormalities is important. Theoretically, prevention of EHD and/or EHDV infection of ungulates can be achieved either by protecting animals from insect attack or prophylactic immunisation (vaccination), but there are difficulties with both of these strategies. For example, elimination of Culicoides midges from the environment is not practical for free-ranging wildlife such as white-tailed deer, nor is housing of pastoral livestock. Protective housing for pastoral livestock would certainly reduce the likelihood of vector attack by minimising exposure to biting midges and allowing for treatment with repellents, but repeatedly rounding up livestock to gather them in enclosures for treatment is not generally a practical option. For farmed livestock, especially valuable animals can be housed in fully insect-protected enclosures to prevent any contact with vector midges during outbreaks. Vaccines to control EHDV infection are not widely available. The notable exception is Ibaraki disease (EHDV-2), for which both inactivated and live attenuated vaccines exist. In Japan, both types of vaccine are available, but in the United States, only locally produced autogenous inactivated vaccines for immunisation of farmed deer are available (57, 98). Any efficacious vaccination strategy would involve the use of vaccines against all serotypes of EHDV endemic in a given area, as humoral immunity is serotype-specific. Although recent studies indicate that the existing live attenuated vaccine to Ibaraki virus, unlike vaccines against BTV, does not cross the placenta after administration to pregnant cattle (G. Savini, unpublished), the potential advantages and disadvantages inherent to inactivated and live attenuated EHDV vaccines are likely the same as those for BTV. This means that there is the potential for live attenuated vaccine strains to be spread vertically in cattle and horizontally by vector midges $(93,98)$.

\section{Conclusions}

Epizootic haemorrhagic disease virus infections of livestock clearly pose an enigma for animal health managers in both endemic and virus-free regions. They can cause very severe disease in the most susceptible species, the white-tailed deer in North America; however, confluent populations of other species of deer become infected without resultant disease, and, internationally, experience shows that in cattle, the only livestock species reported to be affected clinically, infections are usually asymptomatic. Since detectable viraemia in infected animals can be prolonged, especially as detected by PCR assay, the establishment of causality, i.e. the linking of infection to clinical syndromes occurring in an animal during the period of detectable infection, can be problematic. Nonetheless, detailed investigations have led to acceptance that EHDV infections in some circumstances have resulted in disease in cattle. The strains of virus involved have been numerous, involving several EHDV serotypes and occurring in different geographical regions, with viruses that, on the basis of molecular analysis, would seem to be endemic to that region and not an exotic strain from a different continent. The host and virus factors that may lead to the expression of disease are undetermined.

Useful diagnostic technologies for EHDV are well developed and could confidently be transferred to established laboratories wherever EHDV infections pose an animal health problem. As with BTV, while tests that identify infections to the EHDV group level are useful for screening purposes, they are unlikely to be definitive tools for diagnosis or control. To investigate EHDV infections it is necessary to determine serotype and to conduct further molecular analysis of isolates by sequencing to determine likely epidemiologically important relationships. Protection against subsequent infection is serotype specific and so vaccines, if used, must be against the serotype (and preferably the same strain) associated with the disease syndrome. In the United States some commercial deer producers commission autologous vaccines against the viruses infecting their herds, while in Japan, where the Ibaraki strain of EHDV-2 has been linked to disease over a long period of time, commercial EHDV-2 vaccines are available.

Internationally, it is likely that in most circumstances it is the inability to predict the likelihood of future disease outbreaks in livestock, rather than the likely economic impact of any such outbreaks, that has led to concerns regarding EHDV infection. 


\title{
Maladie épizootique hémorragique
}

\author{
N.J. Maclachlan, S. Zientara, G. Savini \& P.W. Daniels
}

\section{Résumé}

La maladie épizootique hémorragique (MEH) est une maladie virale transmise par des arthropodes qui affecte certains ongulés sauvages, en particulier le cerf de Virginie et plus rarement les bovins. Chez le cerf de Virginie, la maladie se manifeste par des lésions vasculaires semblables à celles occasionnées par le virus de la fièvre catarrhale ovine (FCO), auquel le virus de la MEH est étroitement apparenté. Sept sérotypes du virus de la MEH ont été répertoriés ; le virus Ibaraki, responsable de foyers sporadiques chez les bovins asiatiques appartient au sérotype 2. Les infections par les virus de la FCO et de la MEH ont une distribution mondiale et une épidémiologie assez semblables : les deux virus sont présents dans toutes les régions tropicales et tempérées du monde, leur transmission est assurée par les moucherons piqueurs du genre Culicoides et ils infectent de nombreuses espèces d'ongulés domestiques et sauvages. Néanmoins, la distribution mondiale et l'épidémiologie de l'infection par le virus de la MEH sont moins bien caractérisées que celles de l'infection par le virus de la FCO. La plupart des infections naturelles ou expérimentales des animaux d'élevage par le virus de la MEH (à l'exception de celles dues au virus Ibaraki) se présentent sous une forme infra-clinique ou asymptomatique ; néanmoins, des foyers de MEH affectant des bovins ont été récemment notifiés autour du bassin méditerranéen, dans l'île de la Réunion, en Afrique du Sud et aux États-Unis. Des tests de laboratoire fiables et pratiques sont disponibles en nombre croissant pour le diagnostic sérologique et virologique de la maladie, permettant d'obtenir un diagnostic sensible et spécifique de l'infection par le virus de la MEH et de confirmer la présence de la maladie chez les animaux; en revanche, pour ce qui concerne les vaccins, ne sont disponibles dans le commerce que des vaccins contre la maladie d'Ibaraki qui ne confèrent aucune protection contre les autres souches et sérotypes du virus de la MEH.

\section{Mots-clés}

Arbovirus - Moucheron piqueur Culicoides - Vaccination - Virus de la maladie épizootique hémorragique - Virus Ibaraki.

\section{Enfermedadl hemorrágica epizoótica}

\author{
N.J. Maclachlan, S. Zientara, G. Savini \& P.W. Daniels
}

\section{Resumen}

La enfermedad hemorrágica epizoótica (EHE) es una dolencia vírica transmitida por artrópodos que afecta a ciertos ungulados salvajes, en especial el ciervo de cola blanca norteamericano y, más rara vez, al ganado vacuno. En el ciervo de cola blanca, da lugar a lesiones vasculares análogas a las causadas por el virus de la lengua azul, con el que el virus de la EHE guarda estrecho parentesco. De este virus se han descrito siete serotipos. El virus de Ibaraki, que causa esporádicos brotes en el ganado vacuno asiático, pertenece al serotipo 2. La distribución 
mundial y la epidemiología de las infecciones por los virus de la lengua azul y la EHE también son parecidas, pues ambos virus se dan en las regiones templadas y tropicales del mundo, son transmitidos por jejenes Culicoides e infectan a muy diversos ungulados domésticos y salvajes. Sin embargo, el área de distribución mundial y la epidemiología de la infección por el virus de la EHE están menos bien caracterizadas que en el caso de la lengua azul. Aunque la infección natural 0 experimental de ganado vacuno por virus de la EHE (distintos del virus de lbaraki) suele ser latente 0 asintomática, últimamente se han descrito brotes de EHE en bovinos de la cuenca mediterránea, la isla de la Reunión, Sudáfrica y los Estados Unidos. Cada vez hay más pruebas de laboratorio adecuadas y dotadas de la exactitud necesaria para diagnosticar la infección serológica y virológicamente, con sensibilidad y especificidad, y confirmar su presencia en animales, pero comercialmente solo existen vacunas destinadas a prevenir la enfermedad de Ibaraki, que no ofrecen protección contra otras cepas y serotipos del virus de la EHE.

\section{Palabras clave}

Arbovirus - Jejenes Culicoides - Vacunación - Virus de la enfermedad hemorrágica epizoótica - Virus de Ibaraki.

\section{References}

1. Hoff G.L. \& Trainer D.O. (1978). - Bluetongue and epizootic hemorrhagic disease viruses: their relationship to wildlife species. Adv. Vet. Sci. Comp. Med., 22, 111-132.

2. Howerth E.W., Stallknecht D.E. \& Kirkland P.D. (2001). - Bluetongue, epizootic hemorrhagic disease, and other orbivirus-related diseases. In Infectious diseases of wild mammals, 3rd Ed. (E.S. Williams \& I.K. Baker, eds). Iowa State University Press, Ames, 77-97.

3. Maclachlan N.J. \& Osburn B.I. (2004). - Epizootic hemorrhagic disease. In Infectious diseases of livestock, 2nd Ed. (J.A.W. Coetzer \& R.C. Tustin, eds). Oxford University Press, New York, 1227-1230.

4. Savini G., Afonso A., Mellor P., Aradaib I., Yadin H., Sanaa M., Wilson W., Monaco F. \& Domingo M. (2011). Epizootic hemorrhagic disease. Res. Vet. Sci., 91, 1-17.

5. Shope R.E., Macnamara L.G. \& Mangold R. (1960). - A virus-induced epizootic hemorrhagic disease of the Virginia white-tailed deer (Odocoileus virginianus). J. Experim. Med., $111,155-170$

6. Anbalagan S. \& Hause B.M. (2014). - Characterization of epizootic hemorrhagic disease virus from a bovine with clinical disease with high nucleotide sequence identity to white-tailed deer isolates. Arch. Virol., 159, 2737-2740.

7. Beringer J., Hansen L.P. \& Stallknecht D.E. (2000). - An epizootic of hemorrhagic disease in white-tailed deer in Missouri. J. Wildl. Dis., 36, 588-591.
8. Dudley R. (2013). - Epizootic hemorrhagic disease (EHD) outbreak in cattle in Nebraska. Proc. U.S. Anim. Hlth Assoc., 116, 189

9. Gaydos J.K., Crum J.M., Davidson W.R., Cross S.S., Owen S.F. $\&$ Stallknecht D.E. (2004). - Epizootiology of an epizootic hemorrhagic disease outbreak in West Virginia. J. Wildl. Dis., $40,383-393$.

10. Mead D., Stallknecht D., Phillips-Brantley J., Vigil S. \& Corn J. (2012). - SCWDS update: Hemorrhagic disease and Culicoides sp. surveillance. Proc. U.S. Anim. Hlth Assoc., 116, 193.

11. Murphy M.D., Hanson B.A., Howerth E.W. \& Stallknecht D.E. (2006). - Molecular characterization of epizootic hemorrhagic disease virus serotype 1 associated with a 1999 epizootic in white-tailed deer in the eastern United States. J. Wildl. Dis., $42,616-624$

12. Pybus M.J., Ravi M. \& Pollock C. (2014). - Epizootic hemorrhagic disease in Alberta, Canada. J. Wildl. Dis., $50,720-722$

13. Van Campen H., Davis C., Flinchum J.D., Bishop J.V., Schiebel A., Duncan C. \& Spraker T. (2013). - Epizootic hemorrhagic disease in yaks (Bos grunniens). J. Vet. Diagn. Invest., $25,443-446$.

14. Favero C.M., Matos A.C., Campos F.S., Cândido M.V., Costa É.A., Heinemann M.B., Barbosa-Stancioli E.F. \& Lobato Z.I. (2013). - Epizootic hemorrhagic disease in brocket deer, Brazil. Emerg. Infect. Dis., 19, 346-348. 
15. Abdy M.J., Howerth E.E. \& Stallknecht D.E. (1999). Experimental infection of calves with epizootic hemorrhagic disease virus. Am. J. Vet. Res., 60, 621-626.

16. Albayrak H., Ozan E. \& Gur S. (2010). - A serological investigation of epizootic hemorrhagic disease virus (EHDV) in cattle and Gazella subgutturosa subgutturosa in Turkey. Trop. Anim. Hlth Prod., 42, 1589-1591.

17. Al-Busaidy S.M. \& Mellor P.S. (1991). - Epidemiology of bluetongue and related orbiviruses in the Sultanate of Oman. Epidemiol. Infect., 106, 167-178.

18. Aradaib I.E., Mederos R.A. \& Osburn B.I. (2005). - Evaluation of epizootic haemorrhagic disease virus infection in sentinel calves from the San Joaquin Valley of California. Vet. Res. Commun., 29, 447-451.

19. Aradaib I.E., Sawyer M.M. \& Osburn B.I. (1994). Experimental epizootic hemorrhagic disease virus infection in calves: virologic and serologic studies. J. Vet. Diagn. Invest., 6, 489-492.

20. Batten C.A., Edwards L., Bin-Tarif A., Henstock M.R. \& Oura C.A. (2011). - Infection kinetics of epizootic haemorrhagic disease virus serotype 6 in Holstein-Friesian cattle. Vet. Microbiol., 154, 23-28.

21. Bowen R.A. (1987). - Serologic responses of calves to sequential infections with epizootic hemorrhagic disease virus serotypes. Am. J. Vet. Res., 48, 1449-1452.

22. Bréard E., Belbis G., Viarouge C., Riou M., Desprat A., Moreau J., Laloy E., Martin G., Sarradin P., Vitour D., Batten C., Doceul V., Sailleau C. \& Zientara S. (2013). - Epizootic hemorrhagic disease virus serotype 6 experimentation on adult cattle. Res. Vet. Sci., 95, 794-798.

23. Eschbaumer M., Wernike K., Batten C.A., Savini G., Edwards L., Di Gennaro A., Teodori L., Oura C.A., Beer M. \& Hoffmann B. (2012). - Epizootic hemorrhagic disease virus serotype 7 in European cattle and sheep: diagnostic considerations and effect of previous BTV exposure. Vet. Microbiol., 159, 298-306.

24. Gibbs E.P. \& Lawman M.J. (1977). - Infection of British deer and farm animals with epizootic haemorrhagic disease of deer virus. J. Comp. Pathol., 87, 335-343.

25. Homan E.J., Taylor W.P., de Ruiz H.L. \& Yuill T.M. (1985). Bluetongue virus and epizootic haemorrhagic disease of deer virus serotypes in northern Colombian cattle. J. Hyg. (London), 95,165-172.

26. Melville L., Hunt N., Weir R., Davis S. \& Harmsen M. (2005). - Results of a decade of virus monitoring of sentinel cattle in the Northern Territory (1994-2004). In Arbovirus research in Australia, 9th Symposium, 22-17 August, 2004, Noosa Lakes (P.A. Ryan, J.G. Aaskov, T.D. St George \& P.E.R. Dale, eds), 240-245.
27. Quist C.F., Howerth E.W., Stallknecht D.E., Brown J., Pisell T. \& Nettles V.F. (1997). - Host defense responses associated with experimental hemorrhagic disease in white-tailed deer. J. Wildl. Dis., 33, 584-599.

28. Roug A., Swift P., Torres S., Jones K. \& Johnson C.K. (2012). Serosurveillance for livestock pathogens in free-ranging mule deer (Odocoileus hemionus). PLoS ONE, 7, e50600.

29. Ruder M.G., Allison A.B., Stallknecht D.E., Mead D.G., McGraw S.M., Carter D.L., Kubiski S.V., Batten C.A., Klement E. \& Howerth E.W. (2012). - Susceptibility of white-tailed deer (Odocoileus virginianus) to experimental infection with epizootic hemorrhagic disease virus serotype 7 . J. Wildl. Dis., 48, 676-685.

30. Sendow I., Daniels P.W., Cybinski D.H., Young P.L. \& Ronohardjo P. (1991). - Antibodies against certain bluetongue and epizootic haemorrhagic disease viral serotypes in Indonesian ruminants. Vet. Microbiol., 28, 111-118.

31. Toye P.G., Batten C.A., Kiara H., Henstock M.R., Edwards L., Thumbi S., Poole E.J., Handel I.G., Bronsvoort B.M., Hanotte O., Coetzer J.A., Woolhouse M.E. \& Oura C.A. (2013). - Bluetongue and epizootic haemorrhagic disease virus in local breeds of cattle in Kenya. Res. Vet. Sci., 94, 769-773.

32. Tsai K. \& Karstad L. (1973). - The pathogenesis of epizootic hemorrhagic disease of deer: an electron microscopic study. Am. J. Pathol., 70, 379-400.

33. Uren M.F. (1986). - Clinical and pathological responses of sheep and cattle to experimental infection with five different viruses of the epizootic hemorrhagic disease of deer serogroup. Aust. Vet. J., 63, 199-201.

34. Weir R.P., Harmsen M.B., Hunt N.T., Blacksell S.D., Lunt R.A., Pritchard L.I., Newberry K.M., Hyatt A.D., Gould A.R. \& Melville L.F. (1997). - EHDV-1, a new Australian serotype of epizootic haemorrhagic disease virus isolated from sentinel cattle in the Northern Territory. Vet. Microbiol., 8, 135-143.

35. Work T.M., Jessup D.A. \& Sawyer M.M. (1992). - Experimental bluetongue and epizootic hemorrhagic disease virus infection in California black-tailed deer. J. Wildl. Dis., 28, 623-628.

36. Woods L.W., Swift P.K., Barr B.C., Horzinek M.C., Nordhausen R.W., Stillian M.H., Patton J.F., Oliver M.N., Jones K.R. \& Maclachlan N.J. (1996). - Systemic adenovirus infection associated with high mortality in mule deer (Odocoileus hemionus) in California. Vet. Pathol., 33, 125-132.

37. Aguirre A.A., McLean R.G., Cook R.S. \& Quan T.J. (1992). Serologic survey for selected arboviruses and other potential pathogens in wildlife in Mexico. J. Wildl. Dis., 28, 435-442.

38. Aradaib I.E., Mohammed M.E., Mukhtar M.M., Ghalib H.W. \& Osburn B.I. (1997). - Serogrouping and topotyping of Sudanese and United States strains of epizootic hemorrhagic disease virus using PCR. Comp. Immunol. Microbiol. Infect. Dis., $20,211-218$ 
39. Barnard B.J., Gerdes G.H. \& Meiswinkel R. (1998). - Some epidemiological and economic aspects of a bluetonguelike disease in cattle in South Africa - 1995/96 and 1997. Onderstepoort J. Vet. Res., 65, 145-151.

40. Bréard E., Sailleau C., Hamblin C., Graham S.D., Gourreau J.M. \& Zientara S. (2004). - Outbreak of epizootic haemorrhagic disease on the island of Réunion. Vet. Rec., 155, 422-423.

41. Cêtre-Sossah C., Roger M., Sailleau C., Rieau L., Zientara S., Bréard E., Viarouge C., Beral M., Esnault O. \& Cardinale E. (2014). - Epizootic haemorrhagic disease virus in Reunion Island: evidence for the circulation of a new serotype and associated risk factors. Vet. Microbiol., 170, 383-390.

42. Daniels P.W., Sendow I., Soleha E., Sukarsih, Hunt N.T. \& Bahri S. (1995). - Australian-Indonesian collaboration in veterinary arbovirology: a review. Vet. Microbiol., 46, 151-174.

43. Dulac G.C., Dubuc C., Afshar A., Myers D.J., Bouttard A., Shapiro J., Shettigara P.T. \& Ward D. (1988). - Consecutive outbreaks of epizootic hemorrhagic disease of deer and bluetongue. Vet. Rec., 122, 340

44. Gard G.P., Wei R.P. \& Walsh S.J. (1988). - Arboviruses recovered from sentinel cattle using several isolation methods. Vet. Microbiol., 18, 119-125.

45. Gumm I.D., Taylor W.P., Roach C.J., Alexander F.C., Greiner E.C. \& Gibbs E.P. (1984). - Serological survey of ruminants in some Caribbean and South American countries for type-specific antibody to bluetongue and epizootic haemorrhagic disease viruses. Vet. Rec., 30, 635-638.

46. Jori F., Roger M., Baldet T., Delécolle J.C., Sauzier J., Jaumally M.R. \& Roger F. (2011). - Orbiviruses in Rusa deer, Mauritius 2007. Emerg. Infect. Dis., 17, 312-313.

47. Littlejohns I.R., Burton R.W. \& Sharp J.M. (1988). - Bluetongue and related viruses in New South Wales: isolations from, and serological tests on samples from sentinel cattle. Aust. J. Biol. Res., 41, 579-587.

48. Lundervold M., Milner-Gulland E.J., O'Callaghan C.J., Hamblin C., Corteyn A. \& Macmillan A.P. (2004). - A serological survey of ruminant livestock in Kazakhstan during post-Soviet transitions in farming and disease control. Acta Vet. Scand., 45, 211-224.

49. Madani H., Casal J., Alba A., Allepuz A., Cêtre-Sossah C., Hafsi L., Kount-Chareb H., Bouayed-Chaouach N., Saadaoui H. \& Napp S. (2011). - Animal diseases caused by orbiviruses, Algeria. Emerg. Infect. Dis., 17, 2325-2327.

50. Miller M., Buss P., Joubert J., Maseko N., Hofmeyr M. \& Gerdes T. (2011). - Serosurvey for selected viral agents in white rhinoceros (Ceratotherium simum) in Kruger National Park, 2007. J. Zoo Wildl. Med., 42, 29-32.

51. Moore D.L. (1974). - Bluetongue and related viruses in Ibadan, Nigeria: serologic comparison of bluetongue, epizootic hemorrhagic disease of deer, and Abadina (Palyam) viral isolates. Am. J. Vet. Res., 35, 1109-1113.
52. Pasick J., Hanel K., Zhou E.M., Clavijo A., Coates J., Robinson Y. \& Lincoln B. (2001). - Incursion of epizootic hemorrhagic disease into the Okanagan Valley, British Columbia, in 1999. Can. Vet. J., 42, 207-209.

53. Sailleau C., Zanella G., Bréard E., Viarouge C., Desprat A., Vitour D., Adam M., Lasne L., Martrenchar A., Bakkali-Kassimi L., Costes L. \& Zientara S. (2012). Co-circulation of bluetongue and epizootic haemorrhagic disease viruses in cattle in Reunion Island. Vet. Microbiol., 155, 191-197.

54. St George T.D., Cybinski D.H., Standfast H.A., Gard G.P. \& Della-Porta A.J. (1983). - The isolation of five different viruses of the epizootic haemorrhagic disease of deer serogroup. Aust. Vet. J., 60, 216-217.

55. Yadin H., Brenner J., Bumbrov V., Oved Z., Stram Y., Klement E., Perl S., Anthony S., Maan S., Batten C. \& Mertens P.P.C. (2008). - Epizootic haemorrhagic disease virus serotype 7 in cattle in Israel. Vet. Rec., 162, 53-56.

56. Inaba U. (1975). - Ibaraki disease and its relationship to bluetongue. Aust. Vet. J., 51, 178-185.

57. Kitano Y. (2004). - Ibaraki disease in cattle. In Infectious diseases of livestock, 2nd Ed. (J.A.W Coetzer \& R.C. Tustin, eds). Oxford University Press, New York, 12211226.

58. Ohashi S., Yoshida K., Watanabe Y. \& Tsuda T. (1999). - Identification and PCR-restriction fragment length polymorphism analysis of a variant of the Ibaraki virus from naturally infected cattle and aborted fetuses in Japan. J. Clin. Microbiol., 37, 3800-3803.

59. Omori T., Inaba Y., Morimoto T., Tanaka Y. \& Ishitani R. (1969). - Ibaraki virus, an agent of epizootic disease of cattle resembling bluetongue. I. Epidemiologic, clinical and pathologic observations and experimental transmission to calves. Jpn J. Microbiol., 13, 139-157.

60. Uchinuno Y., Ito T., Goto Y., Miura Y., Ishibashi K., Itou T. \& Sakai T. (2003). - Differences in Ibaraki virus RNA segment 3 sequences from three epidemics. J. Vet. Med. Sci., $65,1257-1263$.

61. Gerdes G.H., Neser J.A., Barnard B.J. \& Larsen J. (1996). Stomatitis and coronitis in cattle: an insect-borne viral disease. J. S. Afr. Vet. Assoc., 67, 103-104.

62. House C., Shipman L.D. \& Weybright G. (1998). - Serological diagnosis of epizootic hemorrhagic disease in cattle in the USA with lesions suggestive of vesicular disease. Ann. N.Y. Acad. Sci., 849, 497-500.

63. Kedmi M., Van Straten M., Ezra E., Galon N. \& Klement E. (2010). - Assessment of the productivity effects associated with epizootic hemorrhagic disease in dairy herds. J. Dairy Sci., 93, 2486-2495.

64. Temizel E.M., Yesilbag K., Batten C., Senturk S., Maan N.S., Mertens P.P. \& Batmaz H. (2009). - Epizootic hemorrhagic disease in cattle, Western Turkey. Emerg. Infect. Dis., $15,317-319$ 
65. King A.M., Adams M.J., Carstens E.B. \& Lefkowitz E.J. (eds) (2012). - Virus taxonomy, 9th Ed. Academic Press, San Diego.

66. Anthony S.J., Maan N., Maan S., Sutton G., Attoui H. \& Mertens P.P. (2009). - Genetic and phylogenetic analysis of the core proteins VP1, VP3, VP4, VP6 and VP7 of epizootic haemorrhagic disease virus (EHDV). Virus Res., 145, 187-199.

67. Anthony S.J., Maan N., Maan S., Sutton G., Attoui H. \& Mertens P.P. (2009). - Genetic and phylogenetic analysis of the non-structural proteins NS1, NS2 and NS3 of epizootic haemorrhagic disease virus (EHDV). Virus Res., 145, 211-219.

68. Anthony S.J., Maan S., Maan N., Kgosana L., Bachanek-Bankowska K., Batten C., Darpel K.E., Sutton G., Attoui H. \& Mertens P.P. (2009). - Genetic and phylogenetic analysis of the outer-coat proteins VP2 and VP5 of epizootic haemorrhagic disease virus (EHDV): comparison of genetic and serological data to characterise the EHDV serogroup. Virus Res., 145, 200-210.

69. Maan N.S., Maan S., Nomikou K., Johnson D.J., El Harrak M., Madani H., Yadin H., Incoglu S., Yesilbag K., Allison A.B., Stallknecht D.E., Batten C., Anthony S.J. \& Mertens P.P. (2010). - RT-PCR assays for seven serotypes of epizootic haemorrhagic disease virus \& their use to type strains from the Mediterranean region and North America. PLOS ONE, 17, e12782.

70. Gould A.R. \& Pritchard L.I. (1991). - Phylogenetic analyses of the complete nucleotide sequence of the capsid protein (VP3) of Australian epizootic haemorrhagic disease of deer virus (serotype 2) and cognate genes from other orbiviruses. Virus Res., 21, 1-18.

71. Iwata H., Manabe S., Yoshida A., Pereira E.M. \& Inoue T. (2001). - The complete nucleotide sequences of L3 and S7 segments of Ibaraki virus encoding for the major inner capsid proteins, VP3 and VP7. J. Vet. Med. Sci., 63, 73-78.

72. Nara Pereira E.M., Iwata H. \& Inoue T. (2000). - The complete nucleotide sequence of segment L2 of Ibaraki virus encoding for the antigen recognized by neutralizing antibodies. J. Vet. Med. Sci., 62, 317-321.

73. Ohashi S., Yoshida K., Yanase T. \& Tsuda T. (2002). - Analysis of intratypic variation evident in an Ibaraki virus strain and its epizootic hemorrhagic disease virus serogroup. J. Clin. Microbiol., 40, 3684-3688.

74. Wilson W.C., O'Hearn E.S., Tellgren-Roth C., Stallknecht D.E., Mead D.G. \& Mecham J.O. (2009). - Detection of all eight serotypes of epizootic hemorrhagic disease virus by real-time reverse transcription polymerase chain reaction. J. Vet. Diagn. Invest., 21, 220-225.

75. Mecham J.O., Stallknecht D. \& Wilson W.C. (2003). The S7 gene and VP7 protein are highly conserved among temporally and geographically distinct American isolates of epizootic hemorrhagic disease virus. Virus Res., 94, 129-133.
76. Allison A.B., Goekjian V.H., Potgieter A.C., Wilson W.C., Johnson D.J., Mertens P.P. \& Stallknecht D.E. (2010). Detection of a novel reassortant epizootic hemorrhagic disease virus (EHDV) in the USA containing RNA segments derived from both exotic (EHDV-6) and endemic (EHDV-2) serotypes. J. Gen. Virol., 91, 430-439.

77. Anbalagan S., Cooper E., Klumper P., Simonson R.R. \& Hause B.M. (2014). - Whole genome analysis of epizootic hemorrhagic disease virus identified limited genome constellations and preferential reassortment. J. Gen. Virol., 95, 434-441.

78. Cheney I.W., Larson M.D., Mecham J.O. \& Wilson W.C. (1995). - Geographical genetic variation in the gene encoding VP3 from the Alberta isolate of epizootic hemorrhagic disease virus. Virus Res., 36, 279-286.

79. Cheney I.W., Yamakawa M., Roy P., Mecham J.O. \& Wilson W.C. (1996). - Molecular characterization of the segment 2 gene of epizootic hemorrhagic disease virus serotype 2: gene sequence and genetic diversity. Virology, $224,555-560$

80. Murphy M.D., Howerth E.W., Maclachlan N.J. \& Stallknecht D.E. (2005). - Genetic variation amongst epizootic hemorrhagic disease viruses in the southeastern United States: 1978-2001. Infect. Genet. Evol., 5, 157-165.

81. Sun F., Cochran M., Beckham T. \& Clavijo A. (2014). Molecular typing of epizootic hemorrhagic disease virus serotypes by one-step multiplex RT-PCR. J. Wildl. Dis., $50,639-644$

82. Boyer T.C., Ward M.P. \& Singer R.S. (2010). - Climate, landscape, and the risk of orbivirus exposure in cattle in Illinois and western Indiana. Am. J. Trop. Med. Hyg., 83, 789-794

83. Rosenstock S.S., Ramberg F., Collins J.K. \& Rabe M.J. (2003). - Culicoides mohave (Diptera: Ceratopogonidae): new occurrence records and potential role in transmission of hemorrhagic disease. J. Med. Entomol., 40, 577-579.

84. Smith K.E. \& Stallknecht D.E. (1996). - Culicoides (Diptera: Ceratopogonidae) collected during epizootics of hemorrhagic disease among captive white-tailed deer. J. Med. Entomol., $33,507-510$

85. Lysyk T.J. \& Danyk T. (2007). - Effect of temperature on life history parameters of adult Culicoides sonorensis (Diptera: Ceratopogonidae) in relation to geographic origin and vectorial capacity for bluetongue virus. J. Med. Entomol., 44, 741-751.

86. Lysyk T.J. \& Dergousoff S.J. (2014). - Distribution of Culicoides sonorensis (Diptera: Ceratopogonidae) in Alberta, Canada. J. Med. Entomol., 51, 560-571.

87. Fulton R.W., Burge L.J. \& Cummins J.M. (1989). - Neutralizing antibody responses to bluetongue and epizootic hemorrhagic disease virus serotypes in beef cattle. Am. J. Vet. Res., $50,651-654$ 
88. Aradaib I.E., Brewer A.W. \& Osburn B.I. (1997). - Interaction of epizootic hemorrhagic disease virus with bovine erythrocytes in vitro: electron microscope study. Comp. Immunol. Microbiol. Infect. Dis., 20, 281-283.

89. Stallknecht D.E., Howerth E.W., Kellogg M.L., Quist C.F. \& Pisell T. (1997). - In vitro replication of epizootic hemorrhagic disease and bluetongue viruses in white-tailed deer peripheral blood mononuclear cells and virus-cell association during in vivo infections. J. Wildl. Dis., 33, 574-583.

90. Howerth E.W. \& Tyler D.E. (1988). - Experimentally induced bluetongue virus infection in white-tailed deer: ultrastructural findings. Am. J. Vet. Res., 49, 1914-1922.

91. Howerth E.W., Greene C.E. \& Prestwood A.K. (1988). - Experimentally induced bluetongue virus infection in white-tailed deer: coagulation, clinical pathologic, and gross pathologic changes. Am. J. Vet. Res., 49, 1906-1913.

92. Animal Health Australia (2014). - National Arbovirus Monitoring Program. Available at: www.animalhealthaustralia. com.au/programs/disease-surveillance/national-arbovirusmonitoring-program/ (accessed on 12 August 2014).

93. Maclachlan N.J., Mayo C.E., Daniels P.W. \& Gibbs E.P.J. (2015). - Bluetongue. In New developments in major vector-borne diseases. Part II: Important diseases for veterinarians (S. Zientara, D. Verwoerd \& P.-P. Pastoret, eds). Rev. Sci. Tech. Off. Int. Epiz., 34 (2), 329-340.
94. Clavijo A., Sun F., Lester T., Jasperson D.C. \& Wilson W.C. (2010). - An improved real-time polymerase chain reaction for the simultaneous detection of all serotypes of epizootic hemorrhagic disease virus. J. Vet. Diagn. Invest., 22, 588-593.

95. White J.R., Blacksell S.D., Lunt R.A. \& Gard G.P. (1991). A monoclonal antibody blocking ELISA detects antibodies specific for epizootic haemorrhagic disease virus. Vet. Microbiol., 29, 237-250.

96. Zhou E. \& Afshar A. (1999). - Characterization of monoclonal antibodies to epizootic hemorrhagic disease virus of deer (EHDV) and bluetongue virus by immunisation of mice with EHDV recombinant VP7 antigen. Res. Vet. Sci., 66, 247-252.

97. Della-Porta A.J., Parsonson I.M. \& McPhee D.A. (1985). Problems in the interpretation of diagnostic tests due to crossreactions between orbiviruses and broad serological responses in animals. Prog. Clin. Biol. Res., 178, 445-453.

98. McVey D.S. \& Maclachlan N.J. (2015). - Vaccines for prevention of bluetongue and epizootic hemorrhagic disease in livestock: a North American perspective. Vector Borne Zoonotic Dis., 15, 385-396. 
